\section{NATIONAL INSTITUTE OF ZOOLOGY AND BOTANY, ACADEMIA SINICA}

$\mathrm{T}$ HE research activities in zoology and botany conducted by the National Institute of Zoology and Botany of Academia Sinica during 1943 can be grouped into six sections, namely, ichthyology, entomology, protozoology, phanerogamic botany, algology, and cytology. The results are presented in epitome as follows :

\section{Ichthyology}

For four successive years the important edible fish, Monopterus javanensis, has been the main object of study. The anatomy as well as the physiology of its accessory respiratory organ, namely, the buccopharyngeal epithelium, its breeding habits and metamorphosis and the function of its larval organs have previously been discussed. In 1943 , the whole blood vascular system was carefully worked out, and earlier accounts have required considerable modification. The integumentary serous glands of this fish, with their peculiar distribution around the pericardial region, were studied, and the hatching phenomena with which these glands are chiefly concerned were described. Particularly interesting was an investigation on the sexuality of this fish.; Monopterus starts its life always as a female, undergoes sex-reversal after laying eggs, becoming eventually a male. Its growthrate under natural condition was also studied simultaneously.

As a proof of the capability of hypertonic excretion in a purely freshwater teleost as a means of osmotic regulation, the paradise fish, Macropodus opercultris, was shown in 1942 to produce a crop of chloride-secreting cells in its gill lamellæ when it is acclimatized in a strong sodium chloride solution. In order to ascertain whether the secretory activity of these cells is limited to chloride alone, as their name implies, the same experiment was repeated with sodium sulphate instead of chloride; the result suggests that secretion is not limited to chloride (see Nature, Feh. 26, p. 252).

An ichthyological survey has been made in the region covering Western Szechwan and Eastern Sikang. No less than a hundred species, including ten new ones, were collected and described. A comparative study of the much modified pectoral and pelvic girdles of the Homalopterid fishes, which are adapted with remarkable success to life in torrents, is now being carried on, in the hope of elucidating the phylogenetic relationship within the group.

\section{Entomology}

In systematic entomology, much emphasis has been laid on the white flies, Aleurodidæ, the fruit flies, Trypetidæ, and the leaf beetles, Chrysomelidx. Investigations on the white flies of Szechwan and on the cucumber beetles of China have already been completed, and have proved of value not only to insect taxonomy as a whole, but also to the economic position of the groups studied.

Morphological investigations of insects have also been undertaken. The study of Malpighian tubes in Chrysomelidæ has helped to clear up the systematic position of the sub-family Eumolpinæ. In the study of the tibial tympanic organ of Conocephalus, attention has been directed particularly to the structure of the crista acustica and to the functional aspect of the whole organ. Comparisons of the elytral tracheation of Dermaptera with that of Protelytroptera, a Palæozoic order, were made, and the possibility of the Dermaptera being derived from Protelytroptera was taken into consideration.

Some experiments were conducted to demonstrate the effect of light on orientation of the cicada Cryptotympana pustulata, and also the change of position exhibited by aphids during feeding. Inquiries were likewise attempted with regard to the part played by the elytra of Coleoptera during flight, and by the jumping spiders in checking the spread of house-flies and mosquitoes. Observations on the mode of egg-laying of the aquatic bug, Sphorodems rustica, show that coition is immediately followed by the act of oriposition; the two acts take place alternately and continuously, both activated by the male, and not by the female as generally believed. The problem of respiratory adaptation was investigated in another water bug, Cheirochela sp. This bug, being incapable of rising to the surface of water to obtain atmospheric air, has been obliged to overcome the difficulty by the development of pubescence on the thorax and abdomen for collecting air-bubbles under water, by the modification of certain parts of the integument to permit cutaneous respiration, and, most important of all, by the specialization of the legs to function as tracheal gills.

\section{Protozoology}

In the field of protozoology, work has been confined mostly to the dinoflagellates and Infusoria For the former, studies have been centred in the thecal morphology of dinoflagellates, especially in the plates that constitute the ventral area, which has rarely been scrutinized by previous investigators. The thecal plates of a number of species belonging to Diplopsalis and to Ornithocercus were analysed and their number and arrangement determined. All the specimens studied were collected from the Hainan region during the years 1933 and 1934 .

Surveys of infusorian fauna of Pehpei and other localities of Szechwan have been made from time to time. Five new species of epizoic ciliates were described. They are found attached either to the antennæ, legs and swimmerates or to the gills of the freshwater shrimp, Palcemon nipponensis. Other problems now being studied are the freshwater Sarcodina of Szechwan and the peritrichous Infusoria of Pehpei.

\section{Phanerogamic Botany}

The Umbelliferæ have been the main subject of investigation among the flowering plants. Aside from a general survey of Chinese umbellifers, the species of Bupleurum and Ligusticum, known as native drug plants, were separately treated. The anatomy of seedlings of Coriandrum sativum, Fceniculum vulgare, etc., has also been investigated. The results add much to our knowledge of the development of vascular bundles of the family Umbelliferæ as a whole.

In collaboration with the Kansu Provincial Government, a forest survey is now in progress in that province. Work is proceeding on utilization, growthrate, and fungal disezses of timber trees. Land classification, stand and composition of the existing forests, and dendrological characters, which are exceedingly important for the formulation of forest management plans, are also being examined. 


\section{Algology}

The section of algology dealt largely with the dystematics of freshwater algæ. About 1,500 species were collected from different localities of Kwangtung, Kwangsi and Szechwan, and, among them, 4 genera, 75 species, and 24 varieties were described as new. Asterocapsa, a new genus of Myxophyceæ, is worthy of notice as it has reproductive cells with much the same appearance and mode of development as the more advanced autospores of Chlorophyceæ. Other three new genera, Hormothece, Brachytrichiopsis and Symphyonema, representing transitional forms of certain families, are deemed to be phylogenetically important.

Since 1941, attention has also turned to the study of algal ecology. Observations on algal communities of the Kialing River have been made at regular intervals. As affected by the condition of river-bed, the velocity of water currents, and the intensity of light, the distribution of algæ in this river naturally falls into seven distinct communities, always isolated and never forming horjzontal adjoining zones like those prevalent in stagnant waters. Each community consists of only a single or very few dominant species. In addition, the seasonal distribution of algæ in a freshwater pond was thoroughly studied. Temperature, sunlight and rainfall are factors influencing the periodic occurrence of the species of phytoplankton.

\section{Cytology}

In the field of cytology, investigations on the number and behaviour of meiotic chromosomes of Brachytrupes portentorsus and the meiotic division in Gesonia punctiforons have been completed. The former demonstrates the number and structure of autosomes and the behaviour of the $X$-chromosome, whereas the latter deals especially with chromonema structure and the time of its splitting. In both cases the so-called chromomeres are believed to be mere artefacts or twists in the chromatids.

\section{TRADE AND ECONOMICS IN THE INTERNATIONAL SPHERE}

$\mathrm{T}$ HE Economic, Financial and Transit Department of the League of Nations has issued two studies in a series on international trade and commercial policy with the view of contributing to those objectives of commercial policy, "the elimination of all forms of discriminatory treatment in international commerce" and "the reduction of tariffs and other trade barriers", which have found fresh expression in the Mutual Aid Agreements. The first of these, "Quantitative Trade Controls: their Causes and Nature"*, by Prof. G. Haberler, of Harvard University, in collaboration with $\mathrm{Mr}$. M. Hill, considers what were the forces which induced Governments to adopt these measures of quantitative control; what were the relative advantages and disadvantages of such restriction compared with tariffs and other measures designed to influence trade through the price mechanism; whether quantitative controls were the most suitable instrument, and why they were so generally condemned both by international conferences and by economists, the likelihood of their adoption after the present War and the policies which should then be pursued.

This study leads to the conclusion that if the trend

* League of Nations, II, A.5 ; 1943. Pp. 45. (London: George Allen and Unwin, Ltd.) $28.6 d$. towards economic isolation, autarky, regimentation and State control, characteristic of the nineteenthirties in many parts of the world, were to be renewed after the War, quantitative trade controls would necessarily take an ever-greater role. A movement in this direction would not only belis the intentions of the Governments of the United Nations as expressed in the Atlantic Charter and the Lend-Lease Agreements as well as innumerable statements of national policies; it would also prevent the achievement of those basic economic and social objectives which most of them have proclaimed-greater human welfare and full employment, within the framework of a social system designed to preserve individual liberty. These ends cannot be attained without an expanding international trade. Except over short periods, we cannot have generally regimented and socialized international trade and a domestic economy based on free enterprise.

Many countries may find it necessary to maintain exchange controls for a considerable time after the War as regards capital movements. If effective machinery is established to overcome the initial difficulties of financing the essential needs of countries left after the War without adequate means of external payment, and to facilitate multilateral clearing, it should be possible to liberate commodity trade rapidly from control via the exchanges. Of the circumstances facilitating a removal of import quotas a growth in exports appears to be the commonest, and the whole history of commercial policy in the inter-war period confirms the view that the difficulties in scaling down the barriers to trade are least formidable in times of rising prosperity.

In the period considered, the most clearly discernible factor leading governments to introduce quantitative controls was currency instability accompanied by exchange dumping. A primary cause of the currency instability was the breakdown of the mechanism of international trade and settlements as a result, first of the war dislocation and second of the catastrophic fall in prices. Discrepancies in national price structures can only be overcome by changing prices in terms of domestic purchasing power, or by changing the external purchasing power of currencies by a modification of the exchange-rates. This is one reason in favour of the establishment of special machinery by means of which credit may be furnished to meet changes in the balances of accounts, by which orderly changes in currency parities may, if necessary, be carried through, by which national monetary policies may be co-ordinated and kept in line, and multilateral trade and clearing facilitated.

Such machinery requires for its effective working concerted measures against economic depressions and for the maintenance of full employment, and these elements in a possible long-range plan for the preservation of an international economic system provide a challenge to the constructive vision and the cooperative spirit of our generation. The failure to break down the system of quantitative restrictions in the 'thirties was due not so much to a lack of understanding of the technical issues at stake as to the unwillingness of certain great States to abandon their designs for political aggrandisement or the methods by which they are able to exercise pressure on others. Wise concerted economic measures are one of the bases of a durable peace; but they provide by themselves no solution of the political problem on which the success of all efforts to create a better economic world ultimately depends. 